\title{
Hukum Yang "Berperasaan" Dalam Penyelesaian Konflik Antara Budaya Dan Agama: Penolakan Administratif Terhadap Tradisi Sedekah Laut
}

\author{
'Dumaria Simanjuntak, ${ }^{2}$ Retno Saraswati, Sukirno \\ 'Badan Pemeriksa Keuangan Republik Indonesia, \\ ${ }^{2}$ Fakultas Hukum, Universitas Diponegoro \\ Corespondent Author:dumaria.simanjuntak@bpk.go.id
}

\begin{abstract}
This study aims to explain the meaning of the symbol of the tradition called "Sedekah Laut". It is creates a cultural and religious conflicts frequently and explains how the law should be able to resolve social conflicts by "Berperasaan". This "berperasaan" law is based on progressive legal theory which states that the law must serve the society by providing benefits rather than merely punishing. The results of the discussion showed that there is a strong connection between culture and religion, namely "Sedekah Laut" is a form of practice of the gratitude of the local society to God. This form of gratitude is an expression of gratitude for the gift that has been given. In addition, this is a the way of respect to God who has guarded the sea which is believed to be something important related to the safety of society. The relation of this research to the study of law is that how law can be a tool to resolve conflicts between culture and religion. Resolving conflict by law is done by looking at symbols as cultural values that have been long lived in that local society.
\end{abstract}

Keywords: Culture, Tradition, Law, Values Of Society, Social Conflict,

\begin{abstract}
Abstrak
Penelitian ini bertujuan untuk menjelaskan makna simbol dari tradisi "sedekah laut" yang seringkali menimbulkan benturan budaya dan agama itu terjadi dan menjelaskan bagaimana seharusnya hukum dapat menyelesaikan konflik sosial dengan "berperasaan". Hukum "berperasaan" ini dilandaskan pada teori hukum progresif yang menyatakan bahwa Hukum harus mengabdi kepada masyarakat dengan memberi kebermanfaatan dari pada hanya sekedar menghukumi. Hasil pembahasan menunjukan bahwa ada keterkaitan yang kuat antara budaya dan agama yaitu upacara simbolis Sedekah Laut merupakan wujud implementasi rasa syukur masyarakat setempat kepada Tuhan Yang Maha Esa. Wujud syukur ini sebagai ungkapan terima kasih atas pemberian yang telah diberikan. Selain itu, hal ini sebagai wujud rasa hormat mereka untuk menjaga laut yang diyakini berperan penting demi menjaga keselamatan masyarakat. Kaitan penelitian ini dengan studi hukum adalah bahwa bagaimana hukum dapat menjadi alat menyelesaikan konflik antara budaya dan agama. Penyelesain konflik ini oleh hukum dilakukan dengan melihat simbol-simbol sebagai nilai budaya yang telah lama hidup dalam masyarakat setempat.
\end{abstract}

Kata kunci: Budaya, Tradisi, Hukum, Pandangan Hidup, Konflik Sosial, Konflik. 


\section{A. Pendahuluan}

Tradisi sedekah laut di Pantai Baru Ngentak, Poncosari, Srandakan, Kabupaten Bantul merupakan bentuk budaya berupa pelarungan sesaji ke laut yang biasanya dilakukan masyarakat pada bulan Sura. Seiring perkembangan waktu bentuk dan fungsi sedekah laut mengalami perkembangan dan perubahan karena pengaruh perubahan sosial budaya masyarakat. Sedekah laut ini bukan hanya sekedar ritual namun telah berkembang menjadi fungsi spiritual, fungsi hiburan, fungsi komunikasi, fungsi pelestarian budaya, fungsi pendidikan dan fungsi ekonomi. Perubahan bentuk dan fungsi sedekah laut mempunyai peranan dalam pendidikan bagi masyarakat yaitu pendidikan nilai-nilai luhur bangsa, pendidikan spiritual, pendidikan etos kerja pendidikan pelestarian budaya dan pendidikan pelestarian lingkungan alam. ${ }^{1}$

Seringkali awam mengartikan budaya dengan pengertian sederhana dengan mengatakan bahwa budaya itu adalah seni. Budaya bukan hanya sebatas seni, namun meliputi sebuah jaringan kerja dalam kehidupan antarmanusia. Ada juga yang mengartikan kebudayaan sebagai pandangan hidup dari sekelompok orang dalam bentuk perilaku, kepercayaan, nilai, dan simbol-simbol yang mereka terima tanpa sadar/tanpa dipikirkan yang semuanya diwariskan melalui proses komunikasi dan peniruan dari satu generasi kepada generasi berikutnya. ${ }^{2}$ Kebudayaan mempengaruhi nilai-nilai yang dimiliki manusia. ${ }^{3}$ Dalam buku Teori Komunikasi oleh Little John menjelaskan bahwa, Susanna Langer seorang filsuf, memikirkan simbolisme yang menjadi inti pemikiran filosofi karena simbolisme mendasari pengetahuan dan pemahaman semua manusia. Simbol digunakan dengan cara yang lebih kompleks dengan membuat seseorang untuk berpikir tentang sesuatu yang terpisah dari kehadirannya. Sebuah simbol adalah "sebuah instrumen pemikiran-pemikiran". Simbol adalah konseptualisasi manusia tentang suatu hal, sebuah simbol ada untuk sesuatu. ${ }^{4}$

Bahkan dapat dikatakan budaya dalam simbol mempengaruhi agama dan sebaliknya. Begitu pun dalam hukum, Soekanto menyimpulkan bahwa suatu norma

\footnotetext{
${ }^{1}$ Sri Widati, Tradisi Sedekah Laut di Wonokerto Kabupaten Pekalongan: Kajian Perubahan Bentuk dan Fungsi, Jurnal PP Volume 1, No. 2, Desember 2011 diunduh dari https://journal.unnes.ac.id/nju/index.php/jpppasca/article/viewFile/1538/1714

${ }^{2}$ Alo Liliweri, 2009, Makna Budaya Dalam Komunikasi AntarBudaya, Yogyakarta: PT.LKiS Printing Cemerlang, hlm 8.

${ }^{3}$ Ibid, hlm 7

${ }^{4}$ Little John, Stephen W \& Karen A. Foss, Teori Komunikasi (Theories Of Human Communication) edisi 9. Jakarta : Salemba Humanika, 2009, hlm. 153.
} 
atau kaidah sebenarnya juga merupakan suatu kenyataan yang merupakan gejala kemasyarakatan, seperti perilaku ajeg atau unik ${ }^{5}$ yang sering disebut tradisi/budaya. Kebudayaan yang dimiliki masyarakat pun mempengaruhi hukum dan penegakan hukum di Indonesia. Pemaknaan sempit terhadap budaya ini yang lantas dapat memicu adanya salah pemaknaan akan tradisi yang masih sering dilakukan oleh masyarakat lokal di Indonesia. Salah pemaknaan akan menimbulkan adanya tindakan merasa benar atas kepercayaan yang dianutnya sendiri lalu menyalahkan faham atau aliran lain sehingga dapat mengakibatkan adanya main hakim sendiri.

Kasus-kasus kelompok masyarakat yang membenturkan kegiatan-kegiatan budaya dengan agama cenderung akan mengakibatkan ketakutan di dalam masyarakat yang masih kental melakukan tradisi bahkan konflik sosial serta main hakim sendiri apabila kasus kasus anarkis tersebut tidak segera dimaknai. Masyarakat akan takut menggelar acara sedekah laut atau kegiatan budaya yang akan mengakibatkan lunturnya bahkan punahnya tradisi/budaya nenek moyang yang telah dimiliki Indonesia sejak dahulu yang juga sudah menjadi suatu identitas bagi negara Indonesia. Bahkan jika tradisi yang dijalankan itu sudah dianggap sebagai bagian pengejawantahan dari agama bagi kelompok tertentu, maka kelompok tersebut mungkin merasakan bahwa kebebasan menjalankan agama sudah dilanggar.

Konflik terjadi disebabkan karena perbedaan menempatkan relasi sehingga orang selalu berkomunikasi dengan kekerasan karena perbedaan kebudayaan ${ }^{6}$ atau perbedaan nilai yang dipercayai. Tulisan ini mencoba menjelaskan makna tradisi "sedekah laut" dan bagaimana benturan budaya dan agama itu terjadi. Selain itu utamanya adalah menjelaskan bagaimana seharusnya hukum dapat menyelesaikan konflik sosial dengan adil.

\section{B. Pembahasan}

\section{Makna Sedekah Laut}

Perilaku manusia terkait dengan budaya itu dapat dikatakan bercorak unik. Kebudayaan tradisional di Indonesia sangat beragam. Setiap ragam budaya suatu daerah memiliki makna, nilai dan metode yang satu dengan yang lain tidak sama atau khas. Salah satu ragam dari kebudayaan tradisonal adalah upacara

\footnotetext{
${ }^{5}$ Soerjono Soekanto, 1994, Ulasan Terhadap "Kembali Ke Metode Penelitian Hukum". Dalam Sunaryati Hartono, Penelitian Hukum di Indonesia Pada Akhir Abad Ke-20, Bandung,Alumni, Hlm. 75

${ }^{6}$ Alo Liliweri, 2009, Makna Budaya Dalam Komunikasi AntarBudaya, Yogyakarta: PT.LKiS Printing Cemerlang, hlm 38
} 
tradisional. Upacara tradisional biasanya berkaitan dengan kepercayaan atau religi adalah salah satu unsur kebudayaan yang paling sulit berubah dibandingkan unsur kebudayaan yang lain, misalnya sendratari yang masih sangat jauh dari adanya nilai nilai agama/kepercayaan.

Upacara tradisional yang berkaitan dengan kepercayaan atau religi merupakan upaya manusia untuk mencari keselamatan, ketentraman dan sekaligus menjaga kelestarian kosmos dengan caranya yang khas. Misal upacara sedekah laut. Upacara Sedekah Laut merupakan tradisi turun temurun yang dilaksanakan oleh masyarakat pesisir Pulau Jawa baik pesisir selatan ataupun pesisir utara. Kegiatan ini bertujuan untuk mewarisi kebudayaan turun temurun dari nenek moyang dan memohon perlindungan agar terhindar dari marabahaya selama melaut. ${ }^{7}$

Upacara sedekah laut adalah salah satu perwujudan ungkapan rasa syukur yang dilakukan oleh Kelompok Nelayan. Upacara sedekah laut sebelum hari pelaksanaan didahului dengan prosesi nyekar atau ziarah ke Pantai untuk memohon kepada Tuhan Yang Maha Esa agar tangkapan ikan pada musim panen ikan melimpah dan para nelayan diberi keselamatan. Upacara ini didahului dengan acara prosesi membawa sesaji (Jolen), jolen tunggul yang dibawa Paguyuban Sekartaji berisi puluhan jenis sesaji. Dari mulai kepala kambing, aneka jenis buah, jajan pasar, hingga bentuk panganan dan lauk pauk, sampai sejumlah peralatan dan aksesoris kaum perempuan seperti kain jarit, selendang dan sanggul. Semua jenis sesaji dikemas Jolen tersebut dilarung ke tengah laut lepas Puncak acara tersebut bakal diisi dengan acara utama, kirab prosesi larung sesaji (jolen).

Berbagai sesaji itu mempunyai makna/lambang tersendiri. Beberapa sesaji itu berupa berbagai jenis pisang, jenang dan nasi. Pisang sanggan sebagai lambang bahwa raja atau ratu adalah yang tertinggi. Pisang raja pulut, sebagai lambang pengikut, supaya tetep, lengket, kelet, sehingga hubungan antara raja dengan rakyat itu tetap abadi dan melekat. Jenang palang (merah putih) dengan palang, sebagai lambang supaya masyarakat Ngentak dalam mencari nafkah tidak ada yang menghalang-halangi. Jenang merah putih, sebagai lambang ibu yang melahirkan manusia. Jenang hitam, sebagai lambang persembahan kepada saudara atau kakang kawah adi ari-ari. Nasi ameng, sebagai lambang permohonan

${ }^{7}$ Opcit, hlm. 8 
keselamatan dari Yang Maha Agung. Nasi rasulan/udhuk, sebagai lambang junjungan Nabi Muhammad SAW. Ayam ingkung, sebagai lambang junjungan Nabi Besar Muhammad SAW. Air tawar, sebagai lambang keselamatan. Alat kecantikan dan pakaian wanita, sebagai lambang kesukaan wanita untuk berdandan. Bunga, sebagai lambang permohonan dari keharuman. ${ }^{8}$

Setiap kelompok nelayan akan menampilkan berbagai atraksi kebudayaan dan kesenian. Mereka juga membawa berbagai sesaji dan persembahan untuk dilarung ke Laut Selatan (Samudera Indonesia). Pada malam harinya acara dilanjutkan dengan pertunjukan kesenian tradisional di tiap-tiap desa/ kelurahan oleh kelompok Nelayan yang bersangkutan dalam jolen tunggul berbentuk rumah joglo kecil yang dihias janur dan aksesoris lainnya. Penduduk dusun Ngentak yang sebagian besar beragama Islam ini dikenal dengan upacara adat Sedekah Laut yang ditujukan kepada Sang Penguasa Laut Selatan. Para penduduk mempunyai mitos akan Kanjeng Ratu Kidul atau Nyai Roro Kidul yang menjadi penguasa Laut Selatan yang menguasai Laut Selatan beserta isinya dan kondisi alamnya. Oleh karena itu, para nelayan mengadakan upacara Sedekah Laut untuk memohon kebebasan dari segala marabahaya yang mengancamnya seperti adanya ombak besar, angin besar, dan diberi penghasilan ikan yang melimpah.

Sedekah Laut tersebut juga dimaksudkan sebagai rasa syukur nelayan atas keselamatan dan penghasilan yang berlimpah. Upacara Sedekah Laut di Dusun Ngentak, Desa Poncosari dilaksanakan setiap tahun sekali dan jatuh pada hari minggu pertama di bulan Syawal. Misalnya lebaran pertama jatuh pada hari Rabu, maka pada hari Minggunya dilakukan Upacara Sedekah Laut. Pada tahun 2000, lebaran jatuh pada hari Minggu Wage, 9 Januari 2000, oleh karena itu Sedekah Laut dilaksanakan pada hari Minggu, 16 Januari 2000. Pemilihan hari Minggu pertama di bulan Syawal tersebut dimaksudkan agar saudara-saudara atau anak cucu yang tinggalnya jauh dari Desa Poncosari masih berlibur di rumah orang tuanya sehingga bisa menyaksikan upacara tersebut. Di samping itu, hari Minggu merupakan hari libur sehingga banyak orang yang hadir di Pantai Pandan Simo.

\footnotetext{
${ }^{8}$ Abdurrohman, Muhammad, Memahami Makna Makna Simbolik Pada Upacara Sedekah Laut di Desa Tanjungan Kecamatan Kragan Kabupaten Rembang, The Messenger Volume VII, Nomor 1, Edisi Januari 2015
} 
Acara Sedekah Laut dimulai dengan pembakaran kemenyan dan doa-doa dipimpin oleh Juru Kunci petilasan HB VII. ${ }^{9}$

Masyarakat yang melakukan Sedekah Laut tersebut adalah masyarakat yang berada di pesisir selatan Pulau Jawa yang masyarakatnya percaya akan adanya Nyi Roro Kidul. Upacara ini diadakan nelayan akan menangkap ikan pada musim panen agar ikan melimpah dan para nelayan diberi keselamatan. Kegiatan ini terjadi sebagai salah satu bentuk kepercayaan masyarakat sekitar akan adanya penunggu laut selatan. Masyarakat berharap agar diberi keselamatan ketika mengambil ikan di wilayah laut selatan tersebut. Ketika upacara ini tidak dilaksanakan, marahabaya akan selalu menghantui para nelayan. ${ }^{10}$

Makna sedekah laut diketahui oleh umum untuk memberikan sesuatu pada laut dengan harapan itu baik dengan manusia agar terjalin hubungan antara manusia dengan pencipta alam dengan baik. Sedekah laut selama ini tidak mengganggu masyrakat karena dilakukan di laut. Selain tradisi sedekah laut, masyarakat Jawa memiliki budaya sedekah gunung dan sedekah kali serta merti (bersih) kali. ${ }^{11}$ Masyarakat yang masih melakukan tradisi ini berharap, budaya Sedekah Laut tidak pupus ditelan zaman dengan setiap kali perayaan selalu melibatkan semua generasi agar tertanam jiwa seni budaya untuk melestarikannya.

\section{Latar Belakang Konfllik Sosial Atas Penolakan Tradisi Sedekah Laut}

Latar Belakang pengrusakan di lokasi tradisi sedekah laut di Pantai Baru oleh sekelompok orang menggunakan cadar hitam karena bertentangan dengan agama islam $^{12}$. Padahal menurut masyarakat lokal, semua barang yang dipakai untuk upacara mempunyai makna sebagai persembahan puji syukur pada Yang Maha Agung. Sebenarnya sedekah laut ini merupakan kegiatan budaya yang sudah turun menurun yang setiap tahun dilakukan warga Kabupaten Bantul namun dinilai oleh sekelompok orang yang mengatasnamakan agama islam bahwa tradisi itu bertentangan dengan ajaran agama.

\footnotetext{
9 Ali Wildan, "Tradisi Sedekah Laut Dalam Etika Ekologi Jawa (di desa gempolsewu kecamatan. Rowosari kabupaten. Kendal)”, UIN Walisongo, Semarang, 2015.

${ }^{10}$ Riska Gustiayu Ramadani, Islam Dalam Tradisi Sedekah Lautdi Desa Karangbenda Kecamatan Adipala kabupaten Cilacap, IAIN Purwokerto, 2018

11 https://news.detik.com/berita-jawa-tengah/d-4255714/pdip-diy-ungkap-motif-pembubaran-tradisisedekah-laut-di-bantul

12 https://news.detik.com/berita-jawa-tengah/d-4255067/lokasi-sedekah-laut-bantul-diobrak-abrik-9orang-diciduk-polisi
} 
Namun kenyataannya tidak semua penganut agama islam menganggap bahwa tradisi sedekah laut ini bertentangan dengan agama islam, karena masyarakat yang percaya dengan makna kebaikan diselenggarakannya tradisi sedekah laut ini sebagian besar juga penganut agama islam. Karena itu, apa yang disebut sebagai agama islam atau peradaban islam, dalam realitasnya adalah islam yang dipahami dan diyakini oleh masing-masing umat yang ada di dalam faham dan aliran yang berbeda-beda. Munculnya berbagai faham dan aliran dari kalangan umat islam sendiri, menjelaskan akan adanya beragam penafsiran dan kepentingan di antara umat islam itu sendiri. Ketika berbicara tentang islam ternyata harus ditanyalanjuti, islam menurut faham, aliran atau komunitas apa. ${ }^{13}$

Memang aparat penegak hukum juga sudah langsung bertindak dengan menyita beberapa barang bukti terkait pengrusakan properti acara sedekah laut di Pantai Baru, Bantul. Salah satu barang bukti berupa spanduk bertuliskan penolakan kesyirikan berbalut budaya. Adanya dugaan bahwa kelompok itu membawa senjata tajam saat beraksi juga memperkuat bahwa pengrusakan ini disertai kekerasan. ${ }^{14}$ Namun sampai saat ini kasus ini belum juga selesai. Aparat belum juga menangkap pelaku dan mencari tau motif dibalik tindakan kekerasan tersebut.

Mencari tahu motif kasus benturan budaya dan agama ini tidaklah mudah, perlu dasar untuk menjelaskan makna tradisi masyarakat kepada penganut agama yang membawa kebenarannya sendiri menurut agama yang dianutnya. Bahasa kebenaran itu seharusnya disadari selain ada dalam "kita", ada juga dalam "mereka". Kebenaran harusnya diakui ada di mana mana, di dalam pemahaman kami, kita dan mereka meskipun kesimpulannya berbeda-beda. ${ }^{15}$ Tradisi budaya seharusnya dipahami dari sosial-budaya masyarakat yang bersangkutan, bukan dengan ajaran agama tertentu yang dipaksakan sehingga menimbulkan konflik. Konflik sosial memang tidak dapat dihindari dalam masyarakat Indonesia yang begitu majemuk. Menurut teori konflik bahwa masyarakat senantiasa berada dalam proses perubahan yang ditandai oleh pertentangan yang terus menerus di antara unsur unsurnya.

\footnotetext{
${ }^{13}$ Mudjahirin Thohir, 2007, Memahami kebudayaan: Teori, Metodologi, Dan Aplikasi, Semarang: Fasindo Press, hlm.239.

$14 \mathrm{https} / /$ news.detik.com/berita-jawa-tengah/d-4255454/persiapan-sedekah-laut-diobrak-abrik-polisisita-spanduk-dan-penjor

${ }^{15}$ Opcit, hlm 240.
} 
Teori konflik melihat bahwa setiap elemen memberikan sumbangan terhadap diintegrasi sosial. Teori konflik menilai keteraturan yang terdapat dalam masyarakat itu hanyalah disebabkan karena adanya tekanan atau pemaksaan kekuasaan dari atas oleh golongan yang berkuasa. Oleh sebab itu konflik antara budaya dan agama bukanlah sesuatu yang tabu. Tugas utama menganalisa konflik adalah mengidentifikasi berbagai peranan kekuasaan dalam masyarakat karena kekuasaan senantiasa menempatkan individu pada posisi atas dan posisi bawah dalam setiap struktur. Jika ada individu atau kelompok yang tidak tunduk terhadap kekuasaan yang ada maka terkena sanksi. Dalam masyarakat selalu saja ada pertentangan yang akan menjadi konflik sosial apabila proses pertentangan itu tdk segera dikendalikan. Kondisi politik dan kondisi di komunikasi sosial akan turut menentukan terjadinya konflik sosial. Menurut Dahrendorf konflik akan memimpin ke arah perubahan dan pembangunan karena golongan yang terlibat akan melakukan tindakan yang merubah struktur sosial. ${ }^{16}$

Aparat penegak hukum harus jeli menangani kasus sosial di masyarakat dengan memahami kondisi yang terjadi di Indonesia. Secara hukum, memang kelompok pengrusak kegiatan sedekah laut dapat diberikan sanksi pidana, namun aparat penegak hukum juga harus meluaskan pandangan realitas yang terjadi bahwa dari konflik sosial terjadi juga dapat memberikan sumbangan ke arah pembangunan di mana masyarakat menjadi pintar untuk melihat kasus sosial tidak melulu dari kacamata religi saja, karena budaya/tradisi pun memiliki makna makna yang baik. Masyarakat yang menentang tradisi juga harus paham bahwa realitas adanya tradisi sedekah laut dapat yang tercipta karena ada makna yang juga harus dihargai walaupun makna tersebut bersifat subjektif dan kontekstual dari masyarakat suku Jawa.

\section{Hukum yang "berperasaan" Sebagai Penyelesaian Benturan Budaya dan}

\section{Agama}

Menyelesaikan konflik dengan menggunakan hukum yang berperasaan, perlu memahami paradigma bertemunya budaya dan agama. Pertemuan antara budaya dan agama dapat dilihat dari 2 paradigma yang berbeda. ${ }^{17}$ Yang pertama, apakah agama sebagai peradaban itu otonom sehingga tidak penting untung dikaitkan dengan budaya. Kedua, otonomi agama sebagai peradaban itu tidak ada karena

\footnotetext{
${ }^{16}$ George Ritzer, Sosiologi Ilmu Pengetahuan Berparadigma Ganda, HIm 26

${ }^{17}$ Ibid, hlm 240.
} 
sejatinya kehadiran agama ke bumi, bukan untuk menghapus peradaban lain yang sudah ada melainkan untuk menyempurnakannya. Paradigma pertama artinya agama hanya dipahami dari segi tektualnya saja sehingga tidak dikaitkan sama sekali dengan peradaban lain, sedangkan paradigma kedua melihat agama secara substantivenya sehingga ajaran agama dikenalkan, diserap dan dijadikan acuan perilaku dalam kehidupan bermasyarakat yang berbeda beda peradabannya.

Peradaban kedua inilah, yang cenderung menghasilkan benturan budaya dan agama, apabila masyarakat tidak memahami secara benar. Sentuhan agama dengan peradaban lokal memungkinkan terjadinya macam corak suatu agama. Misalnya saja agama islam dengan peradaban jawa seperti pada kasus di atas. Corak yang pertama adalah antara peradaban islam dan budaya jawa saling menyerap sekaligus menafikan satu dengan yang lain, kedua, peradaban islam menjadi pondasi kuat bagi peradaban masyarakat dan ketiga, budaya lokal lah yang mendominasi masyarakat yang kebanyakan memeluk agama islam. Dari corak inilah muncul islam santri dan islam kejawen. Keduanya mengakui agama islam sebagai agama namun berbeda menempatkan agama dan budaya dalam dominasinya. ${ }^{18}$

Pengrusakan di lokasi tradisi sedekah laut dalam hukum memang dikatagorikan dalam perbuatan pidana dengan melakukan tindakan mengobrakabrik lokasi tradisi sedekah laut, mereka merusak meja dan membanting kursi yang sudah ditatarapi. ${ }^{19}$ Namun untuk motif dari perbuatan pidana oleh sekelompok orang disini ada baiknya tidak ditafsirkan sebagai wakil dari penganut agama islam, mengingat bahwa dalam peradaban islam sendiri banyak faham dan aliran yang tidak menganggap bahwa tradisi sedekah laut merupakan larangan agama islam.

Oleh karena itu selain memproses secara hukum untuk memberi kepastian kepada pencari keadilan bagi masyarakat lokal yang menjunjung tinggi budaya, aparat penegak hukum perlu mengungkap motif kekerasan terhadap kegiatan budaya ini karena dalam kurun waktu berpuluh puluh tahu, tradisi ini tidak pernah ada yang terganggu. Mencaritahu dan mengkaji motif ini perlu agar didapatkan keadilan yang nyata diperlukan oleh masyarakat sehingga hukum bukan hanya dibaca tektual namun juga menggunakan "rasa sentuhan budaya dan agama".

\footnotetext{
${ }^{18}$ Ibid, hlm 241.

19 https://news.detik.com/berita-jawa-tengah/d-4255067/lokasi-sedekah-laut-bantul-diobrak-abrik-9orang-diciduk-polisi
} 
Dengan kata lain, mengkaji hukum dengan mengkaitkan dengan latar belakang permasalah sosial yang terjadi karena adanya kemungkinan kesengajaan pihak yang mencoba membenturkan unsur budaya dan agama di wilayah wilayah Indonesia yang masih kental ritual budayanya.

Menurut Herbert Spencer, keadilan adalah setiap orang bebas untuk menentukan apa yang akan dilakukannya, asal ia tidak melanggar kebebasan yang sama dari orang lain. ${ }^{20}$ Dalam kasus pengrusakan penyelenggaraan tradisi sedekah laut ini, antara masyarakat yang melakukan tradisi sedekah laut dan sekelompok orang pengrusak mengatasnamakan agama memiliki hak kebebasan yang sama untuk menjalankan kepercayaan masing masing namun dalam batasan yaitu tidak melanggar kebebasan satu dengan yang lain dalam melakukan kepercayaannya. Jika melanggar kebebasan maka di situlah pihak yang melanggar berhadapan dengan hukum.

Hukum seharusnya tidak hanya berfungsi menyelesaikan perkara hukum melainkan juga problem sosial. Dari kacamata hukum perkara sudah diputus atau selesai tapi belum tentu sama dengan problem sosial terpecahkan. Hukum memang dijalankan tetapi tidak benar-benar menyelesaikan problem sosial yang dihadapi.

Paul Scholten ${ }^{21}$ memberikan tempat yang sangat terhormat kepada penilaian dalam berhukum, yang artinya bahwa hukum tidak boleh hanya menggunakan logika dalam menilai. Dalam melakukan penilaian berhukum juga dilakukan dengan perasaan. Ronald Dworkin berpendapat bahwa cara membaca teks hukum sebagai moral reading dengan mengatakan "we must try to find language of our own that best captures, in terms we find clear, the content of what the 'framers' intended to say ${ }^{, 22}$. Sejak hukum itu tampil dalam rumusan tertulis atau teks dan teks tersebut dipakai untuk menghukumi kejadian nyata dalam masyarakat, maka menjadi penting untuk mencocokkan teks tersebut dengan fakta di masyarakat namun Paul Scholten mengatakan apa yang terjadi tidak sesederhana itu.

Makna yang dibuat dalam teks itu sering masih membuka perdebatan pendapat sehingga pekerjaan mencocokkan tidak sederhana. Pekerjaan

\footnotetext{
${ }^{20}$ Satjipto Rahardjo, Ilmu Hukum, 2014, Bandung: PT Citra Aditya Bakti, Hlm. 174

${ }^{21}$ Paul Scholten, De Structuur der rechtswetenschap, atau Struktur Ilmu Hukum, terj. B. Arief Sidharta. Bandung: Penerbit Alumni, 2003.

${ }^{22}$ Ronald Dworkin, Fredom's Law: The Moral Reading of American Constitution, New York: Oxord University Press Inc., 1996, pages 8.
} 
menghukumi suatu kejadian bukan hanya didasari bunyi teks, karena orang juga dapat mengartikan teks itu dengan lebih halus. Melalui metode penghalusan hukum muncul makna lain dari teks asli sehingga terhadap fakta itu tak dapat begitu saja diterapkan bunyi teks yang lama. Hukum merupakan otoritas besar yang menata kehidupan manusia bermasyarakat. Artinya menundukkan perilaku dan hubungan-hubungan antar manusia di bawah kekuatan memaksa dari hukum. ${ }^{23}$ Oleh karena masyarakat sebagai realitas memiliki kehidupan yang kompleks maka hukum harus bisa melihat kejadian dan proses dalam masyarakat sebagai satu rangkaian kelanjutan dan kaya dengan variasi sehingga perlu dilakukan hukum yang "berperasaan" yang artinya hukum yang tidak saklek melihat kasus sosial yang masuk ranah hukum diselesaikan hanya dengan melihat teks yang ada. Hukum yang progresif yang melihat kebermanfaatan dari pada hanya sekedar menghukumi.

\section{Simpulan}

Makna dilakukannya Tradisi Sedekah Laut adalah sebuah rasa syukur kepada Tuhan Yang Maha Esa, atas segala nikmat dan karunia yang diperoleh pada masa kehidupan manusia terutama untuk masyarakat nelayan di Pulau Jawa. Selain nilai sakral yang dianut, prosesi Sedekah Laut juga bertujuan untuk melestarikan kebudayaan. Tradisi sedekah laut tanpa melihat makna kontektual yang dipahami oleh masyarakat yang masih melestarikan budaya ini sebagai ungkapan syukur kepada Tuhan ini oleh sekelompok masyarakat yang mengatasnamakan agama tertentu menjadi latar belakang konflik sosial terhadap penolakan budaya berupa pengrusakan dengan membenturkan pada ajaran agama.

Hukum yang menyelesaikan konflik sosial adalah hukum yang menggunakan paradigma. Benturan budaya dan agama dipandang sebagai bertemunya budaya dan agama di mana apabila terjadi gesekan, hukum harus bisa melihat kejadian dan proses dalam setiap konflik sosial dalam masyarakat sebagai satu rangkaian kelanjutan variasi sehingga perlu dilakukan hukum yang "berperasaan" yang artinya permasalahan sosial tidak diselesaikan hanya dengan melihat teks yang ada saja namun harus menyelesaian kasus sosial yang sama supaya tidak lalu muncul dan tenggelam lalu muncul lagi. Hukum harus mengabdi

\footnotetext{
${ }^{23}$ Satjipto Rahardjo, Berpikir Hukum Secara Rasional, Jurnal Hukum Progresif, Volume 1, Edisi 1, April 2013, Hlm. 26.
} 
kepada masyarakat dengan memberi kebermanfaatan dari pada hanya sekedar menghukumi. Hukum harus dapat mengakomodir "rasa" tersebut.

\section{Daftar Pustaka}

Liliweri, Alo, 2009. Makna Budaya Dalam Komunikasi Antarbudaya, Yogyakarta: PT LKiS Printing Cemerlang.

Little John, Stephen W \& Karen A. Foss. 2009. Teori Komunikasi (Theories Of Human Communication) edisi 9. Jakarta : Salemba Humanika.

Rahardjo, Satjipto, 2014. Ilmu Hukum, Bandung: PT Citra Aditya Bakti.

Berpikir Hukum Secara Rasional, Jurnal Hukum Progresif, Volume 1, Edisi 1, April 2013

Ritzer, George, 1985.Sosiologi Ilmu Pengetahuan Berparadigma Ganda, Jakarta: CV. Rajawali

Sri Widati, Tradisi Sedekah Laut di Wonokerto Kabupaten Pekalongan: Kajian Perubahan Bentuk dan Fungsi, Jurnal PP Volume 1, No. 2, Desember 2011

Soekanto, Soerjono, 1994. Ulasan Terhadap "Kembali Ke Metode Penelitian Hukum”. Dalam Sunaryati Hartono, Penelitian Hukum di Indonesia Pada Akhir Abad Ke-20, Bandung: Alumni

Scholten, Paul. (2003). De Structuur der rechtswetenschap, atau Struktur Ilmu Hukum, terj. B. Arief Sidharta. Bandung: Penerbit Alumni.

Thohir, Mudjahirin, 2007. Memahami kebudayaan: Teori, Metodologi, Dan Aplikasi, Semarang: Fasindo Press

Thohir, Mudjahirin, Bahan Ajar, Interpretative Approach in social sciences

Abdurrohman, Muhammad, 2015. Memahami Makna Makna Simbolik Pada Upacara Sedekah Laut di Desa Tanjungan Kecamatan Kragan Kabupaten Rembang, The Messenger Volume VII, Nomor 1, Edisi Januari 2015, http://journals.usm.ac.id, diunduh 28 Oktober 2018 pukul 20.00.

Ramadani, Riska Gustiayu, 2018. Skripsi "Islam Dalam Tradisi Sedekah Laut di Desa Karangbenda Kecamatan Adipala kabupaten Cilacap", IAIN Purwokerto.

Wildan, Ali, 2015. Skripsi "Tradisi Sedekah Laut Dalam Etika Ekologi Jawa (di desa gempolsewu kecamatan. Rowosari kabupaten. Kendal)", UIN Walisongo, Semarang.

https://news.detik.com/berita-jawa-tengah/d-4255714/pdip-diy-ungkap-motifpembubaran-tradisi-sedekah-laut-di-bantul, 1 November 2018 pukul 13.00

https://news.detik.com/berita-jawa-tengah/d-4255067/lokasi-sedekah-laut-bantuldiobrak-abrik-9-orang-diciduk-polisi, 1 November 2018 pukul 13.00

https://news.detik.com/berita-jawa-tengah/d-4255454/persiapan-sedekah-lautdiobrak-abrik-polisi-sita-spanduk-dan-penjor, 1 November 2018 pukul 13.00

https://news.detik.com/berita-jawa-tengah/d-4255067/lokasi-sedekah-laut-bantuldiobrak-abrik-9-orang-diciduk-polisi, 1 November 2018 pukul 13.00 